\title{
Developing Paradigms, Patterns, and Mechanisms for Science Teachers' Professional Development in Area-Based Networks in Thailand
}

\author{
Nattakit Sawadthaisong* \\ Department of Science Education, Faculty of Education, Ubon Ratchathani Rajabhat University, Thailand \\ *Corresponding Author: nattakit.s@ubru.ac.th
}

\section{ABSTRACT}

The main purpose of this research was to develop a paradigm, pattern, and mechanism for the professional development of science teachers in area networks that were consistent with the needs of educational institutions according to the key priority agenda for development. The target groups used in this study were teacher production institutions and educational institutions in the northeastern region of Thailand. Research tools included data collection forms and questionnaires. The collected data were analyzed by standard statistical methods, including frequency, percentage, mean, standard deviation, priority need index, and content analysis. The results revealed that the paradigm, pattern, and mechanism for science teachers' professional development found in the northeastern area-based networks of Thailand were individual-based development (ID), spiral patterns (SP), and multiple networks (MN). Individual-based development was a new paradigm of professional development that emphasized the driving force and quality from within by progressive and individualized programs using students' outcome-based development. The SP was a professional development model emphasizing self-paced learning with diversity and an integrated model through blended, action-based learning, both on-the-job training and off-the-job training, using coaching and mentoring from the teacher production institution in the area. The MNs were a professional development mechanism cooperating and supported by a school, university, private sector, and local and national affiliation using school-based development. The way forward is to form a professional learning community using a cooperation network in a school which acts as a mechanism to drive policies for cooperative practice. Recommendations are offered as a result of this study.

KEY WORDS: Area-based Teacher Training; Professional Development Mechanism; Professional Development Paradigm; Professional Development Pattern; Science Teacher Development

\section{INTRODUCTION}

E mpowering people to improve their educational competency in the $21^{\text {st }}$ century, an era of rapid change is a key point of the development in many countries toward sustainable progress (AACTE, 2010; OECD, 2018). The quality of education is an important variable that is the main point and contextual aspect of education reform for the development of many countries to have the potential to drive sustainability on the world stage (Office of the Education Council, 2018). As shown in comparative studies of international education on educational performance, Thailand's competitiveness in education has decreased in comparison to the other Association of South East Asian Nations (ASEAN) countries. Although Thailand was ranked higher than Indonesia and the Philippines, it was ranked lower than Malaysia and Singapore (IMD, 2017; 2018).

The results of program for International Students Assessment (PISA) assessments in 2015 and 2018, which are key indicators of the overall educational quality in the country, showed that Singapore and Vietnam were the only two ASEAN countries in the world's top ten. The other four ASEAN counties in the assessment: Malaysia, Thailand, Indonesia, and the Philippines were below the OECD average. When considering students' performance in science - a subject important for most counties as science has been reported to be the foundation of economic development and competition (OECD, 2016; 2019)only Singapore and Vietnam were at the top of world rankings. The results of PISA 2018 assessments focusing on scientific literacy showed that Malaysia, Thailand, Indonesia, and the Philippines performed below the OECD average. Thailand had a low level of teaching performance in comparison to other Asia-Pacific countries. Thailand has invested more in education than every other ASEAN country except Malaysia (OECD, 2013; IMD, 2016; Office of the Education Council, 2018).

The results of the educational assessment showed that the fundamentals and contexts of different countries do not directly vary with the country's competitiveness in education. However, despite this difference, there is something in common, that is, the teachers. Teachers are organizers of education in the classroom; they are close to and directly in contact with the 
learning of the students (Simola, 2005; Newcombe et al., 2009). Therefore, the key variables that make schools successful in educational management are the quality of teachers and learning resources (Sternberg and Horvath, 1995; Wenglinsky, 2001; Smith and Strahan, 2004; OECD, 2010). The quality of education not only depends on the curriculum and modern technology but also deeply relates to the quality of teachers who are in the process of implementing the curriculum based on the context of each school. Teachers can design, build, and develop education management that is suitable for the context of the class. Schools and learning methods according to the teachers' practices under the framework of the core curriculum learning standards are defined by the country act as a guideline for classroom management for science teachers (Darling-Hammond and Bransford, 2005; Brown, 2009; McMillan, 2011).

The background and reasons mentioned show that Thailand's professional development mechanisms and patterns are currently unable to improve quality education for its people. Therefore, teacher development using the idea of area-based networks is a new way to reform the paradigm of professional development for Thai science teachers. The reformed paradigm will be the main way of creating and developing a pattern and mechanism for the development of science teachers' competency together in the cooperative network. Teacher production institutions are an important network driving the shift of the standard of Thai students' science literacy compared to the international competition.

\section{Research Objectives}

The objectives are as follows:

1. To study current and desirable conditions for the paradigm, pattern, and mechanism for science teachers' professional development in area-based networks of Thailand

2. To develop the paradigm, pattern, and mechanism for science teachers' professional development in the area networks that are consistent with the need for educational institutions according to the key priority agenda for development.

\section{METHODOLOGY}

This research consisted of two steps. The first step was to study current and desirable conditions of the paradigm, pattern, and mechanism for science teachers' professional development in area-based networks of Thailand. The second step was an examination of the paradigm, pattern, and mechanism for science teachers' professional development in the area networks, which was consistent with the needs of educational institutions according to the key priority agenda for development.

For step one, data resources included annual reports on performance, human resource management, and academic services for science teacher development provided by the teacher production institutes in the north-eastern region of
Thailand, as well as a self-assessment report and statistics on schools' science teacher development. The north-eastern region is the largest region of Thailand with more schools and teachers more than another region. It was chosen due to the proximity the author's university which is one of Thailand's teacher production institutes.

\section{Participants}

The participants in this study were divided into two groups.

Group 1: The teacher production institute group included participants from north-eastern region's teacher production institutions: Rajabhat University and the Rajamangala University of Technology. The total for the target groups was 98 persons, including: (1) Personnel and staff involved in human resource management and academic services in science teacher development, (2) faculty and department/curriculum administrators, and (3) instructors/researchers involved in the development of science teachers.

Group 2: Participants in the school group included schools affiliated with the Office of the Basic Education Commission, affiliated with local government, and affiliated with the Office of the Private Education Commission that are expected to receive teacher development services from the teacher production institutions. The total target for this group was 3849 persons, including: (1) School directors and deputy directors, (2) head teachers of a science learning group, and (3) science teachers.

\section{Research Tools}

Research tools included: (1) The teacher production institutions' data collection forms, (2) the schools' data collection forms, (3) the teacher production institutions' questionnaires, and (4) a school questionnaire.

The data were collected by the teacher production institute group using the data collection form which included: (1) The number of instructors/researchers classified by departments and educational backgrounds, (2) the number of students classified by programs offered, (3) expertise considering the highest qualification and teaching/research experiences, (4) roles and responsibilities for teacher development, (5) current curriculum/projects of professional development and academic service areas (for the last 5 years), and (6) curriculum/projects of professional development and service areas expected for academic service in the future (2019-2023), including curriculum/projects provided by teacher production institutions and invited by other institutions.

The data collected by the school group using the data collection form included: (1) The number of teachers classified by the department; (2) the number of teachers classified by curriculum offered; (3) teacher expertise as measured by the highest qualification and teaching/research experience; (4) the quality of education of the school for the past 3 years, including the results of the national test (NT), the Ordinary National Education Test (O-Net), and the vocational national educational test (V-Net); and (5) the teacher development of the 
school classified for the last 5 years and for the future (20192023), both teacher development organized and developed by the school and academic development services received from teacher production institutions and the other institutes.

The data collected by the teacher production institute group using a questionnaire included: (1) Gender, age, educational background, position, and experience in position; (2) current condition and desirable condition of paradigm, pattern, and mechanism of teacher development in area-based network; and (3) recommendation for a paradigm shift and transformation of the pattern and mechanism of science teacher development, including factors of strengthening for teacher development in the present and in the future.

The data collected by the school group using the questionnaire included: (1) Gender, age, educational background, position, experience in the position, and type of educational institution; (2) current condition and desirable condition of paradigm, pattern, and mechanism of teacher development in the areabased network; and (3) recommendation for a paradigm shift and transforming of the pattern and mechanism of science teacher development, including factors of strengthening for teacher development in the present and in the future.

\section{Data Analysis}

The data collected by the data collection form were analyzed in general for frequencies and percentages, for mean and standard deviation of the quality of education management in the last 3 years, and for expertise, curriculum/projects, service areas, and professional development.

The data collected from the questionnaire were analyzed for mean, standard deviation, and content of current and desirable conditions of the paradigm, pattern, and mechanism for science teachers' professional development in area-based networks, including recommendations.

\section{Second Step}

As stated, the second step was an examination of the paradigm, pattern, and mechanism for science teachers' professional development in the area networks, which is consistent with the need of educational institutions according to the key priority agenda for development. A draft was made of the paradigm, pattern, and mechanism for science teachers' professional development in the area networks that were consistent with the need for educational institutions according to the key priority agenda for development.

The priority need for the paradigm, pattern, and mechanism for science teachers' professional development in the area networks, which was consistent with the need of educational institutions collected from the first step, was analyzed through the use of this modified version:

$$
\mathrm{PNI}_{\text {modified }}=(\mathrm{I}-\mathrm{D}) / \mathrm{D}
$$

whereIrepresented the mean of desirable conditions of the paradigm, pattern, and mechanism for science teachers' professional development in the area-based networks that were required and needed to exist in the future, $D$ represented the mean of current conditions of the paradigm, pattern, and mechanism for science teachers' professional development in the area-based networks.

The priority needs and desirable conditions of the paradigm, pattern, and mechanism for science teachers' professional development were analyzed in the area-based networks of educational institutions.

The paradigm, pattern, and mechanism for science teachers' professional development were analyzed using content analysis and drafted for the area-based networks that were consistent with the need of educational institutions according to the key priority agenda for development.

The suitability, possibilities, and benefits of drafting paradigms, patterns, and mechanisms for science teachers' professional development in the area-based networks consistent with the need of educational institutions were evaluated according to the key priority agenda for the development through focus groups. The experts' focus groups were from teacher production institutes and schools. The experts from the teacher production institutes consisted of teacher development policymakers, faculty and department/curriculum administrators, and department/curriculum professors/instructors/researchers. The experts from the schools consisted of school administrators and administrators at educational institutions affiliated with the provincial and national teacher development organization.

The results section presents the complete version of the paradigm, pattern, and mechanism of the science teachers' professional development in the area-based networks that are consistent with the need of educational institutions according to the key priority agenda for development.

\section{RESULTS}

The results of the questionnaire about the current and desirable conditions of the paradigm, pattern, and mechanism for science teachers' professional development in area-based networks in the the north-eastern region of Thailand showed (see Figure 1) that the current paradigm was a traditional paradigm based on institutional command. The desired condition was a new paradigm based on teachers' competency-based development and students' outcome-based development.

The desired conditions of the pattern were offline and on-thejob training through action-based learning.

The current mechanism was an organization mechanism that consists of professional development by provincial and local affiliations and by the teacher production institutes in the service area. The desired condition was an organization mechanism of professional development by school and a network of professional development by a cooperative network of three organizations and five organizations.

\section{Paradigm}

The paradigm for science teachers' professional development was based on the idea of area-based networks in the north- 
eastern region of Thailand, which was consistent with the need for educational institutions according to the key priority agenda for development. The desired new paradigm for the science teachers' professional development was individual-based development (ID), which has three important characteristics: (1) The driving force and quality coming from within teachers, (2) a progressive individualized program, and (3) students' outcome-based development. The way to use this paradigm is as follows:

1. Science teachers' professional development comes from a driving force and quality within teachers according to a competency-based individual action plan that progresses along teachers' career paths

2. Science teachers' outcome-based professional development by individual demand and individually determined content works according to the students' individually determined content

3. Science teachers' professional development comes by way of professional institutional direction through the use of performance-based progressive and individualized programming.

\section{Pattern}

The new pattern for science teachers' professional development found in the north-eastern area-based networks of Thailand was the spiral pattern (SP). The SP has three important characteristics: (1) Self-paced learning with a diverse and integrated model; (2) blended, action-based learning, both on-the-job training and off-the-job training; and (3) coach- and mentor-based learning from the teacher production institution in the area. The way to use this pattern is as follows:

1. Science teachers' professional development is off-thejob training by blended learning to accord to self-paced learning integrated among action training and seminars, learning through an excellent model school and an online course based on individually defined learning that uses both the school and the teacher production institute

2. Science teachers' professional development is on-the-job training through action-based learning that uses coaching and mentoring systems run by teacher production institutions

3. Science teachers' professional development is achieved through cooperative networks of the learning community in the school and with other schools through both online and offline systems.

\section{Mechanism}

The new mechanism for the science teachers' professional development found in the north-eastern area-based networks of Thailand was multiple networks (MN). The main characteristics of the MN were that they cooperated and supported mechanisms by school, university, private sector, and schools' local and national affiliations using school-based development. The way to use this mechanism is to form a professional learning community using a cooperation network that acts as a mechanism to drive policies for cooperative practice. Holistic cooperation between educational institutions, teacher production institutions, the private sector, local communities, and local and national affiliations is required.

\section{DISCUSSION}

Individual-based development (ID) is the new paradigm for science teachers' professional development found in the north-eastern area-based networks of Thailand. The main characteristics of the ID are professional development using the driving force and quality that comes from within teachers who use progressive individualized programming based on students' outcomes. This finding leads to changing and inverting the paradigm of professional development from the traditional paradigm to a new one that emphasizes teachers' competency development under the country's teacher professional standards. This paradigm uses professional advancement as a driving force within teachers through the enrichment process to concretely develop individual teachers based on the context of the area for the students' outcome. Instead of defining ideas from directed organizations or institutes, the same process is used for everyone in all areas. This is an important new concept for teacher development that is consistent with the national strategy for 2018-2047 on the development and empowerment of human resources and the National Economic and Social Development Plan issue 12 (2017-2021), which emphasizes that people at the center of development should be complete people: discipline, knowledge, skills, and creativity. It is also consistent with the strategy of the Ministry of Education on the production and development of teachers and educational personnel. In the past, students have had low levels of national science test results compared to others, and the international scientific test results are low compared to ASEAN member states and the rest of the world. These results reflect one of the causes of Thai labor problems: Thailand lacks knowledge, skills, and attitudes that meet the needs of the labor market, and this lack affects the economic development of the country.

Therefore, science teachers' professional development has to be suitable for teachers' needs and students' outcomes and use a paradigm that emphasizes students' outcome-based learning. This finding is consistent with the results of the international studies of Spady (1994), Lawson and AskellWilliams (2007), and Cheng et al. (2010). There is a group of countries with higher international scientific test results than Thailand has. This means that professional development based on the driving force and quality within the teacher is the process that empowers internal-to-external teachers. ID also emphasizes the spirit as a precursor to the path of thinking, ideas, speaking, and actions contributing to sustainability. Teachers should therefore set self-improvement goals based on the concept of self-introduction and define requirements and learning objectives, designing experiences and resources that facilitate their learning, as well as self-evaluation. This is consistent with Cheng et al. (2010), who consider self-directed learning as the ability to learn because of self-motivation. However, the main point of the new paradigm for teacher development must be adaptable to the country's goals and 
area context and consistent with requirements for professional development based on individual teachers' progress focused on performance that affects students' outcomes. This finding is consistent with research results in Hungary, which found that teacher development courses must be flexible and dynamic, able to drive teachers to progress and respond to the needs of learners, schools, localities, and the world (Pesti et al., 2017).

The SP is the new pattern for science teachers' professional development found in the north-eastern area-based networks of Thailand. The main characteristic of the SP is professional development based on self-paced, action-based learning with a diverse and integrated model, both on-the-job training and offthe-job training as blended learning. This pattern is also based on coaching- and mentoring-based learning from the teacher production institution in the area. The emphasis of this pattern is to provide teachers with multidimensional development under the roles and duties defined by the professional development organization as a model of spiraling constructive intervention. This helps and supports teachers' overviews on the professional career path, the relationship of the professional career path that is being driven to their clearly professional destination. Science teachers' professional development based on this research idea is consistent with people development by leading organizations abroad. They believe that development with only teacher training, which Thailand normally uses to develop teachers, is not enough to develop the professional competency required of specialists (Jennings, 2011). The other important characteristic of the SP is action-based learning, both on the job and off the job, as blended by cooperative research with the university, which is a teacher production institution that serves the area. This cooperative research with

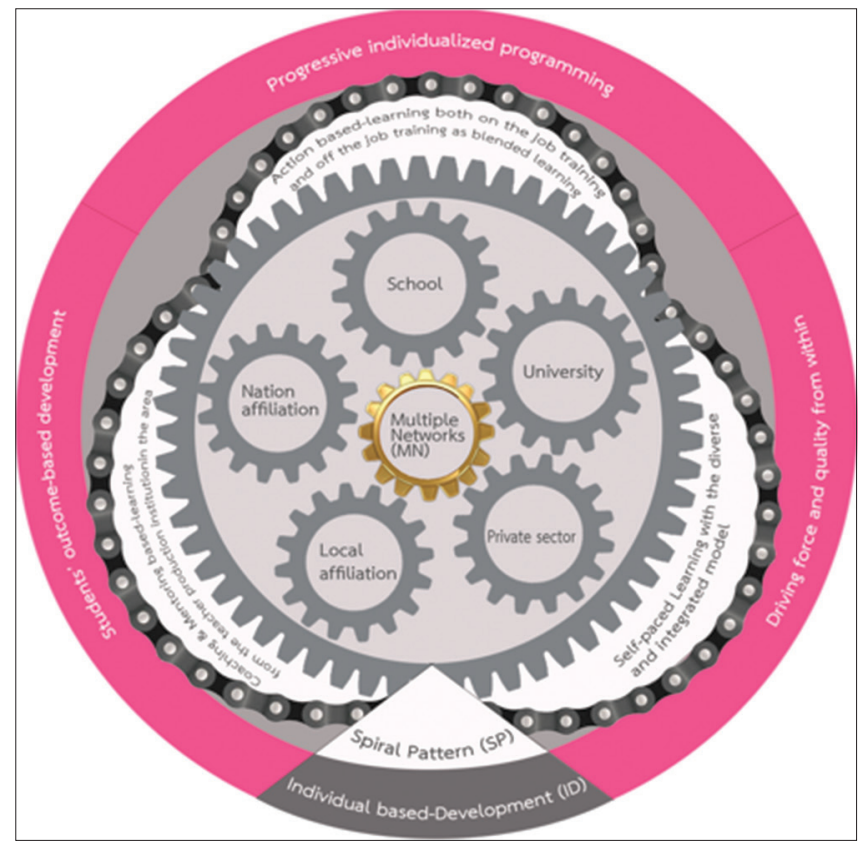

Figure 1: The paradigm, pattern, and mechanism for science teachers' professional development found in the northeastern area-based networks of Thailand the university helps teachers to not only understand students' learning styles but also develop educational innovation. The teacher production institutions that have experts in research for teaching and learning development deeply understand the local school context. They can be coaches and mentor for teachers to promote and develop the teachers' competencies in the academic service area. The idea from this research is consistent with the OECD's findings that teacher development through cooperative research with universities can help teachers achieve their professional development.

Learning by doing on the job, blended with off-the-job online training, and integrating technology in online networks is effective for professional development. There are many advantages to online learning, such as saving time, reducing costs, and preventing the spread of Covid-19, as well as the exchange of experience and knowledge, which is an important process of acquiring knowledge, positive perspectives, and new experiences (Peters and Burbules, 2004). Sharing and learning through professional learning communities on online networks occur naturally when there are enough resources and experts (Zhang et al., 2007).

MNs are the new mechanism for science teachers' professional development found in the northeastern area-based networks of Thailand. The main characteristics of the $\mathrm{MN}$ were cooperation and supporting mechanisms provided by school, university, private sector, and local and national affiliations using school-based development. This area network is cooperative, and each organization has clear roles and duties; all sectors operate in constructive interference and harmony. The success is driven most importantly by provincial or local authorities. This research finding agrees with the idea of area network cooperation driven by local authorities propounded by Dyson et al. (2012).

The MN for science teachers' professional development involves five facets. First, the school is the most important educational institution for developing students' achievement. Second, the university, the teacher production and development institute, is the academic center for continuous development and support of teachers and schools. The university is an academic environment for professional development for in-service teachers and is also designed for research to be conducted with local educational institutions. The cooperative research results show that teachers need to return to the classroom as students, which is consistent with allowing alumni to return to study and be developed through programs provided by the university, namely, the Lifelong Learning Initiative of Singapore National University (National University of Singapore, 2021). Third, the private sector determines the qualification of applicants for positions, which leads to the expectation that graduates will enter the labor market and is an important force in participation that will bring about change in the education sector. Fourth, local communities, including persons, wisdom, and places, play an important role in supporting schools in all areas; schools and the local communities where their students live 
need to understand and reach out to each other to promote, help, and support each other. Finally, the schools' local, provincial, and national affiliations are units that promote the overall drive of teacher development mechanisms.

\section{RECOMMENDATIONS}

The paradigm, pattern, and mechanism for developing science teachers based on area network concepts are consistent with the needs of schools according to key issues that need to be accelerated. The area network is a concept that will lead to reform of the traditional teacher development paradigm, patterns, and mechanisms. It can be used for further research on the development of teachers according to the concept of area-based networks to achieve concrete results for learners.

\section{ACKNOWLEDGMENTS}

The author would like to express sincere gratitude to the following for their support and assistance: Office of the Education Council (research grant), Professor Dr. Pruet Siribanpitak (research project advisor), co-research project team from Chulalongkorn University, Mahasarakham University, and Rajamangala University of Technology Isan. Further sincerely thanks to all other associates and colleagues from the faculty of education of Ubon Ratchathani Rajabhat University who were involved throughout the process of conducting this research.

\section{REFERENCES}

AACTE. (2010). 21 ${ }^{\text {st }}$ Century Knowledge \& Skills in Educators Preparation. London, United Kingdom: Pearson.

Brown, M.W. (2009). The Teacher-tool Relationship: Theorizing the Design \& Use of Curriculum Materials. United Kingdom: Routledge.

Cheng, S.F., Kuo, C.L., Lin, K.C., \& Lee-Hsieh, J. (2010). Development $\&$ preliminary testing of a self-rating instrument to measure the selfdirected learning ability of nursing students. International Journal of Nursing Studies, 47(9), 1152-1158.

Darling-Hammond, L., \& Bransford, J. (2005). Preparing Teachers for a Changing World: What Teachers Should Learn \& Be Able To Do. United Kingdom: John Wiley \& Sons.
Dyson, A., Kerr, K., \& Raffo, C. (2012). Area-based initiatives in Engl\&: Do they have a future? Revue Française de Pédagogie, 178, 27-38.

IMD. (2016). World Competitiveness Yearbook 2016. India: IMD Publishing. IMD. (2017). World Competitiveness Yearbook 2019. India: IMD Publishing. IMD. (2018). World Competitiveness Yearbook 2019. India: IMD Publishing. Jennings, C. (2011). Inside Learning Technologies \& Skills: How Subjectsbased Education in School Ruins Our Conception of Learning. India: Closer Still.

Lawson, M.J., \& Askell-Williams, H. (2007). Outcomes-based Education. United States: Association of Independent Schools of SA.

McMillan, J.H. (2011). Classroom Assessment: Principles \& Practice for Effective St\&ards-based Instruction. 5 $^{\text {th }}$ ed. United Kingdom: Pearson.

National University of Singapore. (2021). NUS L3. Available from: https:// www.scale.nus.edu/sg/lifelong-learning/alumni.

Newcombe, N.S., Ambady, N., Eccles, J., Gomez, L., Klahr, D., Linn, Mi., Miller, K., \& Mix, K. (2009). Psychology's role in mathematics \& science education. American Psychologist, 64(6), 538-550.

OECD. (2010). PISA 2009 Results in Focus. Paris, France: OECD Publishing. OECD. (2013). PISA 2012 Results in Focus. Paris, France: OECD Publishing. OECD. (2016). PISA 2015 Results in Focus. Paris, France: OECD Publishing. OECD. (2018). The Future of Education \& Skills Education 2030. Paris, France: OECD Publishing.

OECD. (2019). PISA 2018 Results in Focus. Paris, France: OECD Publishing.

Office of the Education Council. (2018). Thai Education Competency in the World. India: Prigwhan.

Pesti, C., Rapos, N., Nagy, K., \& Bohán, M. (2017). Analysis of learning outcome-based teacher training programmes: Development experiences in Hungary. Acta Paedagogica Vilnensia, 38(38), 58-76.

Peters, M.A., \& Burbules, N. C. (2004). Poststructuralism \& Educational Research. United States: Rowman \& Littlefield.

Simola, H. (2005). The Finnish miracle of PISA: Historical \& sociological remarks on teaching \& teacher education. Comparative Education, 41(4), 455-470.

Smith, T.W., \& Strahan, D. (2004). Toward a prototype of expertise in teaching: A descriptive case study. Journal of Teacher Education, 55(4), 357-371.

Spady, W.G. (1994). Outcome-based Education: Critical Issues \& Answers. United States: American Association of School Administrators.

Sternberg, R.J., \& Horvath, J.A. (1995). A prototype view of expert teaching. Educational Researcher, 24(6), 9-17.

Wenglinsky, H. (2001). Teacher Classroom Practices \& student Performance: How Schools Can Make a Difference. United States: Educational Testing Service.

Zhang, J., Scardamalia, M., Lamon, M., Messina, R., \& Reeve, R. (2007). Socio-cognitive dynamics of knowledge building in the work of 9-\& 10-year-olds. Educational Technology Research \& Development, 55(2), $117-145$. 